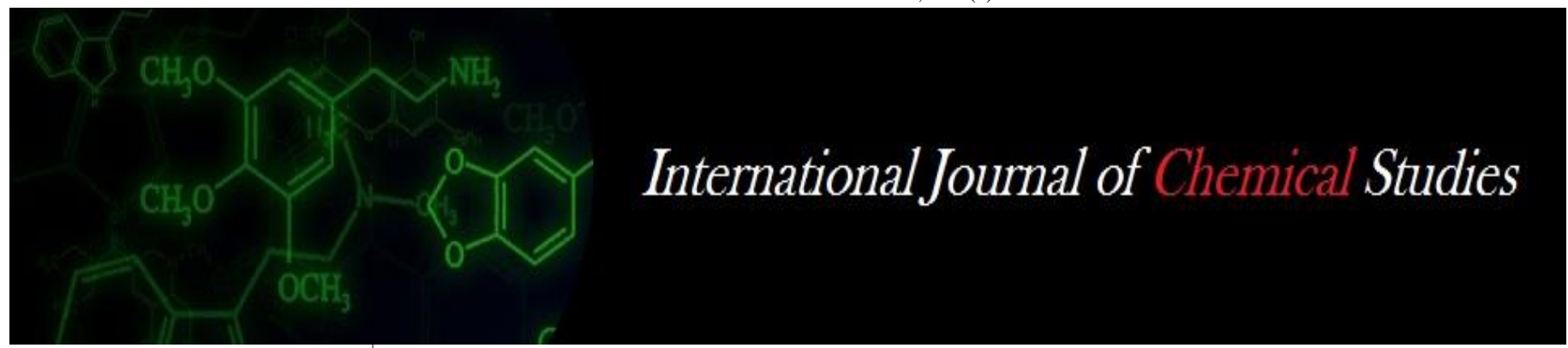

P-ISSN: 2349-8528

E-ISSN: 2321-4902

www.chemijournal.com

IJCS 2020; SP-8(2): 56-61

(C) 2020 IJCS

Received: 05-01-2020

Accepted: 07-02-2020

Mamta Vyas

Assistant Professor, Department

of Agriculture, Mandsaur

University, Mandsaur,

Madhya Pradesh, India

Prashant Sinoriya

Assistant Professor, Department

of Agriculture, Mandsaur

University, Mandsaur,

Madhya Pradesh, India

\section{Impact of information and communication technology (e-agriculture) on agriculture and rural development}

\author{
Mamta Vyas and Prashant Sinoriya
}

DOI: https://doi.org/10.22271/chemi.2020.v8.i2b.9538

\begin{abstract}
This paper presents a review of the different study done by different researchers. Regarding impact of information and communication technology on agriculture and rural development after knowing the research done by various researcher, investigator and experts concluded that ICTs play a vital role in sustainable agriculture and rural development; rural community development. ICTs have remarkable contribution towards improvement of economic and social development of over all the world. In developing country like India, to create information to empower poor people, sustainable development of rural area dissemination of ICT in major level of rural villages is necessary further, Agricultural extension is an educational service which brings information and new technologies to farming communities to enable them improve their agriculture production, yearly incomes and level of living. With the problem that extension agents face in facilitating direct contact with farmer and with researchers due to the physical distances involved and lack of transportation needed for their mobility, the application of Information and Communication Technologies offers excellent possibilities in agriculture development and also development of rural areas. This review paper presents the background introduction, survey, literature review and analysis of information systems in agriculture and rural development. The usefulness of information for agriculture, sources of agricultural information, types of information necessity for agricultural development, problems of dissemination of agricultural information are discussed in this review paper.
\end{abstract}

Keywords: Agriculture extension, agriculture information dissemination

\section{Introduction}

According to the findings of Maningas et al. (2000) ${ }^{[29]}$, information within the hands of the farmers means empowerment through control over their resources and decision-making processes. They noted that being an effective and efficient delivery system of essential information and technology services facilitates the clients' critical role in decision-making towards improved agricultural production, processing, trading, and marketing. Food and Agriculture Organization points out, information is very important for rural development because improving the income of farming community will depend crucially upon raising agricultural productivity. Achieving sustainable agricultural development is less based on material inputs (e.g., seeds and fertilizer) than on the people involved in their use. For achieving this there is a need to focus on human resources for increased knowledge and information sharing about agricultural production, as well as on appropriate communication methodologies, channels and tools. Literature review provides a logical picture of the study. It is helpful for conducting a successfully Study about the subject. The review of past investigations in particular investigating area gives many key points and guidelines to the investigator and researcher to carry out study in particular area. ICTs has proven, to be valuable contribution for solving agriculture development related issues and problems of rural development and perform successful task in Agriculture, Education, Industries, Banking, Business, etc. in rural and urban area of country and hence ICT becomes a most popular tool of all human beings aspect of life in rural and urban society. Review presented below includes literature related to impact of Information and Communication Technology and its Tools on agriculture and rural development as well as application of Information and Communication Technology for Rural Development and related aspects.
Corresponding Author: Mamta Vyas

Assistant Professor, Department of Agriculture, Mandsaur

University, Mandsaur,

Madhya Pradesh, India 


\section{Main Objectives of Review of Literature}

The main objectives Review of Literature is:

1. To identify role of ICTs in Agriculture and rural development.

2. To identify agricultural information system components, their availability, the problems associated with them and how to improve their execution.

3. The objective of this paper is to find out the contribution of information and communication technologies to the agricultural extension system.

\section{Information and Communication Technology (ICT)}

ICT is the combination of three words "information", "communication", and "technology". We all are using communication to disseminating the information and the information transmitted by the technology. In other term ICT is also known as e- Agriculture. And in digital age ICT play a major role in agriculture and rural development.

\section{Review of Literature on Some Related Studies to satisfying all Three Stated Objectives}

1. To Identify Role of ICT in Agriculture and Rural Development: Following are some studies taken from different sources referenced to identify role of ICTs in rural development through Information and Communication Technology and its Tools.

1. Indiresan (1989) ${ }^{[17]}$ The modern technology and computer dominated technology will rapidly replace the conventional production technologies but basically their value is as information processors and concluded that all development is rely on knowledge and as knowledge transmission and dissemination which is more difficult in rural areas as compared to cities, electronic and computer systems are a greater necessity for rural development than for urban development.

2. Neelameghan (1998) ${ }^{[34]}$ published an article, "Information Technology and Rural development". This paper focus on the scope and issues relating to rural development and use of emerging information and communication technologies to support rural development, and related policies and strategies. In this article the author noted that the rural people has a three- purposes relating to information and communication, such as to enable them become more productive and efficient in their economic activities; to enhance their capacity to disseminate the valuable native knowledge they gain ; to facilitate reliable village data collection and analysis needed for development planning. And also author suggested that the rural communities and individuals need to be empowered by enhancing their capacity to access, select and use information as a basis for and in tandem with all other development efforts whether they relate to literacy, food, health and family welfare, population growth, environment, trade and employment

3. Malik and Bhardwaj (2001) ${ }^{[28]}$ made an inquiry on the strategy of using IT for rural development.

According to the authors in the nineties Indian society has been witness of transformation of from an industrial society to an information society.

This change made by Information Technology, telecommunication, computing and microelectronics. Increasing deployment of IT application which determining factor in social and economic issues, the boom in satellite and cable T V channels, introduction of Mobile phones, India world on internet the large international network connecting 30 lakh computers, all these are a sign that arrive information society in the country. The authors also said that these new information technologies can provide enormous possibilities in agriculture and Rural Development sector. Moreover the use of these technologies needs to be planned very accurately at the village level.

4. Gulati Archana (2008) ${ }^{[12]}$ published a paper entitled as "Dialing in rural prosperity through universal cellular connectivity" and concluded that mobile connectivity has tremendous potential to transform rural India. The Mobile connectivity can improve rural productivity, reduce dependence and can ensure that rural schemes actually meet to their planed benefits and thus sustainable growth for our country is possible.

5. P. Syama Thrimurthy (2009) [38] published an article entitled as "Information communication technology for rural areas". In this paper, author made an attempt present the importance of ICT, initiatives of ICT for rural areas and the obstacles that are to be faced while implementing various ICT projects of different States \& Union territories for enhancing employment generation, agriculture counseling, entrepreneurial activity, increase market access, education and knowledge, to addressing health challenges, rural empowerment, women empowerment of women, good governance, etc. to upward the rural live hood.

2. To Identify Agricultural Information System Components, their Availability, the Problems Associated with Them and How to Improve their Execution-

Analysis of Agricultural Information Systems: When analyzing agriculture information systems we should look for the sources of information, the content of information, the exchange (both receive and transfer) of information, the extent of the information contact, the degree of usefulness and the reason for not using it, the type of information needed and so on.

\section{Sources of Agricultural Information}

Information source is an institution or individual that creates or brings about a message (Statrasts, 2004) ${ }^{[49]}$. The characteristics of a good information source are relevance, timelessness, accuracy, cost effectiveness, reliability, usability, exhaustiveness and aggregation level (Statrasts, 2004) ${ }^{[49]}$. According to Oladele (1999) ${ }^{[35]}$, the efficiency of technologies generated and disseminated depends on effective communication which is the key process of information dissemination. The development of agricultural technologies requires among other inputs, a timely and systematic transmission of useful and relevant agricultural information (messages) through relatively well educated technology dissemination (extension) from formal technology generation system (research) via various communication media (channels) to the intended audience-farmers (Oladele, 1999) ${ }^{[35]}$. It is expected that the message from the client (effect) be passed back to the source or research (feedback) for the communication process to be complete.

The study by Opara, (2008) [36] investigated the sources of agricultural information available to farmers in Imo State, Nigeria as well as the farmers' preferred sources. The results mentioning that that 88.1 percent of the farmers indicated agricultural extension agents as their source of information, 71.2 percent indicated fellow farmers, 63.2 percent indicated radio, 43.3 percent indicated television, etc. The results further showed that majority (70.0 percent) preferred the extension agent to the other media (radio 28.4 percent, friends and relatives 27.2 percent, television 19.1 percent, etc.) The 
results emphasize the need for the extension agency to regularly identify those sources of information that farmers prefer, or use most, as this will enable them deliver agricultural information effectively to the farmers.

\section{Types of Information Received}

The study conducted by Rees et al (2000) ${ }^{[40]}$, on agricultural knowledge and information systems

(AKIS) undertaken by the Kenya summarizes the types of information obtained by farmers. It is mentioning that technical information was reportedly received by 16-33 percent of farmers.

However, most end users felt that information flow for this category was particularly deficient; the major knowledge gap expressed in the feedback meetings in all four districts was for technical information (e.g. how to manage late blight in potatoes, where to get certified seed, the most appropriate varieties for a given location, housing and management of livestock, etc.). Other information types it mentioned are marketing information and operational information.

\section{Methods of Analyzing Agricultural Information Systems}

Limited numbers of studies have discussed the methods for analyzing the agricultural information systems (Röling, 1988) [42]. Some studies (Jones et al., 1987; Rolls et al., 1994; Ramkumar, 1995; Ortiz, 1997; Demiryürek, 2000; Boyaci, 2006) $[21,43,39,37,8,5]$ had only used the frequency of information contact with various information sources in order to measure the information score. On the other hand, Rolls et al. (1999) ${ }^{[44]}$ and Rolls and Slavik (2003) ${ }^{[45]}$ had separately analyzed the extent of the contact and the degree of the information usefulness. Demiyürek et al. (2008) [9] and Demiryürek (2010) ${ }^{[10]}$ used the Total Information Score (TIS), which is a combined variable of the frequency of contact with information sources and their usefulness. Thus, the TIS reflects not only the quantity but also the quality of the information contact. Information scores for each component of the information systems can be calculated by multiplying the number of the information contact (weight) with the degree of information usefulness (TIS $=$ number of contact $\times$ usefulness of information).

\section{Problems of Agricultural Information Dissemination}

There are some limiting factors and apparent constraints in agricultural information dissemination in many developing countries. One of the obvious constraints in the use of the broadcasting media in many cases in developing countries is poor reception quality and the area covered. The messages carried are not tailored to the information needs of rural populations. Even when the information is relevant, it is seldom aired at the proper time and so does not get to the targeted audience. Another major constraint is the use of print media: leaflets and newsletters as message carriers are of limited use in reaching illiterate farmers. Technical language used in communicating information is incomprehensible to the farmers. Another major constraint to agricultural information dissemination is the inadequacy of existing extension programs 2 . Some of these programs are conceived without well thought out plans and are prepared in a hurry without the farmers whose attitudes are to be changed making any input. Such agricultural information packages can neither sustain the farmers' interest nor effect the desired attitudinal as a whole. Technological advances and software packages developed with the hope of promoting efficiency in the information dissemination practices of research institutions and universities, or even in the companies of the developed countries, have not in reality brought benefit to farmers. Moreover, the small size of farms, illiteracy among farmers, the lack of organizational unity among farmers, and the instability of national agricultural policies have all played a part in undermining the effectiveness of the agricultural information delivery. This demonstrates how vital aspects of the agricultural information system have not worked properly, with information failing to reach users in timely or effective fashion (Kizilaslan, 2006) ${ }^{[25]}$.

The objective of this paper is to find out the contribution of information and communication technologies to the agricultural extension system- A research conducted in Ethiopia related to find out the contribution of information and communication technologies to the agriculture extension system is given below-

Contribution of information and communication technologies (ICTs) to the Ethiopian agricultural extension system Even though the history of broadcast media in Ethiopia is relatively old, its development has been so slow until the last decade, when the expansion of both governments owned and the private media have been noted. The electronic media, which is still under government ownership, has increased its airtime very recently and also its coverage of development issues has expanded. Radio stations, mainly FM stations, have tremendously increased and the installation of community radio stations is being considered by private and government institutions. These all in one way or another way deal with issues especially related to the Press Law of Ethiopia, the government does not control the content and concepts expressed in such publications. The Broadcast Agency of Ethiopia regulates the broadcast media (radio and television). Similarly, telecommunication is regulated by the Ethiopian Telecommunications Agency. The regulatory activity serves to promote a broader communication of agricultural and rural development information and to provide affordable telephone (both fixed and mobile) and Internet services as well as nonIP services such as radio and television.

Effective knowledge and information management in the agricultural sector were achieved with the right knowledge and information delivered to the farmers and other stakeholders at the right time in a user-friendly and accessible manner. Farmers were involved in the knowledge management process as knowledge generated in a participatory manner and have a greater likelihood of being accepted and acted upon the knowledge. This participatory approach was enabled the integration of traditional or tacit knowledge of farmers with the modern forms of knowledge, and further enhances the utilization of knowledge disseminated to smallholder farmers.

\section{Forms of Information and Communication Technologies (ICTs) in Agriculture}

ITU (2009) ${ }^{[18]}$ argues number of challenges in using ICT in agriculture in Africa. The first challenge has to do with how ICTs are understood and perceived. In talking about ICTs there is emphasis on the Internet and associated technologies, leading to a narrowing of the context of ICTs to computers and the Internet. With the current mobile boom in Africa, the context has shifted to cell phones, computers and the Internet. This perception can result in other technologies such as radio and TV being sidelined or overlooked, a critical issue in Africa where half of rural households have a radio and $6 \%$ have TV, whereas only $2.6 \%$ have access to fixed telephones and $0.38 \%$ have access to the Internet. 
Kevin and Mark (2011) argue radio is the most widely used medium for disseminating information to rural audiences across Africa. Radio can reach communities at the very end of the development road people who live in areas without phones or electricity. Radio reaches people who cannot read or write. Even in very poor communities, radio penetration is vast. There are more than 800 million radios in developing countries. An average of one in ten people in Africa have access to a radio; that translates into a major proportion of households that own radios, given that the average household size is 7.2 people. An AFRRI survey of 4581 households in rural listening communities in countries confirmed that approximately $76 \%$ of households own a. radio Over the years many development initiatives have demonstrated the power of radio to reach rural audiences, both as an instructional technology, and as a participatory development medium.

Ethiopia has made significant stride in rolling out infrastructure to various part of the country through Rural Connectivity Project, Woreda Net, School net and Agri Net, but this has yet to make dent on the flow of indigenous knowledge. Many people still see the Internet as a consumption tool as a means of recreation, information gathering and shopping, but the Internet has been a key resource for exchange of agricultural information. A significant amount work still remains in turning Internet and other technologies around to facilitate the exchange of agricultural information.

\section{Generation and Use of Agricultural Information in Ethiopia}

In Ethiopia, public agricultural extension services have been in action for about half a century. Ethiopia has the largest agricultural extension system in Sub-Saharan Africa, and third largest in the world after China and India (Swanson and Rajalahti, 2010) ${ }^{[47]}$. According to the Bill and Melinda Gates Foundation, a total of 8,500 farmer training centers (FTCs) have been established and 63,000 field extension workers (known as development agents-DAs) have been trained. The current extension approach, therefore, follows FTC-based extension system. The FTCs are positioned to facilitate agricultural knowledge and information exchange among researchers, extension workers and farmers. Woreda level agricultural offices are responsible for managing the operation of FTCs with the support of zonal and regional agriculture bureaus and are the frontline administrative structure for implementing agricultural extension services in the country. The experts (called subject matter specialists-SMS) in each woreda provide technical support and training to DAs. Most of the FTCs have at least three development agents one for crops, livestock, and natural resource management.

Knowledge management can be defined as the fact or condition of knowing something with a considerable degree of familiarity acquired through experience, association or contact. Knowledge consists of the attitudes, cumulative experiences, and developed skills that enable a person to consistently, systematically and effectively perform a function. It is an integration of explicit and tacit knowledge. Explicit knowledge refers to all aspects of formal, systematic, recorded, communicated and shared knowledge that is made accessible through a variety of information delivery systems. Tacit knowledge on the other hand is highly personal, created by doing, trial, error, reflection and revision. Knowledge is considered as the fourth production factor after labor, land and capital (Lishan, 1999) ${ }^{[26]}$ and is particularly critical in the agricultural sector. Making relevant knowledge accessible to the farming community helps improve production, productivity and brings higher returns. If the agricultural practice of smallholders is not backed up by modern agricultural knowledge and information, agricultural households are likely to remain trapped in low productivity, food insecurity and poverty. In the context of Ethiopia, generating new agricultural knowledge and information and making it available for use by smallholder farmers is important in promoting sustainable livelihoods and reducing rural poverty. Various entities are engaged in the creation and development of information and knowledge. Likewise, several repositories and intermediaries play their role to bring the information and knowledge to the ultimate users. Agricultural knowledge is created from modern and indigenous sources. The modern knowledge is created through scientific research (and therefore it is explicit knowledge) by universities and research institutes. Indigenous knowledge or tacit knowledge, on the other hand, refers to traditional knowledge, innovations and practices of local communities and is developed outside the formal education system.

Agricultural information and knowledge created from these sources is stored in various forms before it is disseminated for use. The main repositories of such knowledge in Ethiopia include publications, audio visuals, and websites. The stored knowledge and information is then disseminated to users, such as rural farmers, through intermediaries notably during trainings, field visits, exhibitions, publications, and using traditional forms of ICT (TV and radio), modern forms of ICT (internet, mobile phone, etc), and others.

Effective knowledge management is achieved when the right knowledge and information is delivered to the right person at the right time in a user friendly and accessible manner that helps the recipients to perform their jobs efficiently. The outcome of effective knowledge management includes improved productivity and performance of the agricultural sector.

Smallholder farmers in Ethiopia as well as elsewhere in the developing world require up to date knowledge and information in order to effectively and efficiently perform their farming practices. The knowledge and information that farmers demand ranges from accessibility of new farming methods, availability of weather forecast and supply as well as price of inputs and outputs, among others. In Ethiopia, various institutions and organizations are engaged in the creation, collection, storing, and dissemination of agricultural knowledge and information. The most notable ones, in terms of having direct linkage with the farmers, are institutes of agricultural research and the Ministry of Agriculture. Agricultural research institutes are the prime source for the creation of agricultural knowledge and information in the country (Mulat, 2002) ${ }^{[21]}$.

The initiative of Farm Radio International (FRI) is one best case in the use of ICT for agriculture. FRI, a Canadian based not-for-profit organization, started its operation in Ethiopia in June 2011. It operates in direct partnership with some local radio broadcasters where it supports them to build the necessary skills to develop content that responds to the needs of local small-scale farmers. In order to provide the radio broadcasters with news and resources that help meet the needs of small-scale farmers, FRI produces a weekly publication called Farm Radio Weekly that is delivered to e-mail inboxes every week with free subscription. FRI also prepares and collects agriculture related knowledge and information and produce radio script that is used by the partner broad casters. 


\section{Conclusion}

After discussed about all aspects of paper now we can conclude the result of various observation and research further As discussed in the paper, majority of the farmers of rural area are not having access most of the required agricultural information. Therefore, application of e- agriculture and information and communication technology based on agriculture information support systems is necessary for the dissemination of agricultural information and technological. To betterment of information systems in agriculture it is highly recommend to establish communication between farmers, extension workers, coordinators, agricultural experts, agriculture research centers, and community by information technology. The information should be according to farmers' needs, internet used as a medium to transfer the advanced agricultural information to the rural area. So these conditions also should be considered when implementation of better information systems for agriculture and rural people.

The analysis of the agricultural information systems it may be identify of the main components and networks of the system. This approach is also useful to define the problems and to improve the information management system. For effective utilization of agricultural information in this age, it is very important to establishment of information centers. Such type of information centers would be able to provide very beneficial information to farmers. For effective dissemination of agricultural information in rural communities by extension workers, KVK and other responsible persons, there is need for improve the system of technology transfer in overall the country.

The government organizations have been playing a vital role in introducing and disseminating Information and Communication Technology systems to agricultural extension service delivery. In this regard, the role played by Information and Communication Technology in disseminating agricultural system is perfect. The findings of this study reveal that the different forms of ICT have been used in agricultural service delivery. ICT play a very important role in sustainable agriculture and rural development. According to this study it is clear that ICT have a positive impact on rural development. India is a developing country and in this respect to improve the condition of rural people is very necessary and ICT play a vital role in this aspect.

\section{References}

1. Atul D. Newase et al. Indian Journal of Computer Science and Engineering (IJCSE) A literature review on impact of information and communication technology tools on rural society of India.

2. Allen DW, Ochs MA. Building pathways out of rural poverty through investments in agricultural information systems. World Agro Info Design Team Final Report, 2008.

Link:www.worldaginfo.org/files/WorldAgInfo\%20Final $\% 20$ Report\% 20Web.pdf.

3. Alex Koutsouris WS1.1-Innovation and change facilitation for rural development the emergence of the intra-rural digital divide: A critical review of the adoption of ICTs in rural areas and the farming community.

4. Bhavnani A, Won-Wai RC, Janakiram S, Silarsky P. The role of mobile phones unsustainable rural poverty reduction, ICT policy division, global information and communication department, 2008.

5. Boyaci M. "A Comparison of Conventional and Ecological Agricultural Knowledge Systems in Turkey:
Raisin Case". Journal of Sustainable Agriculture. 2006; 28:5-23.

6. Caseli F, Coleman WJ. Cross country technology diffusion: The Case study of Computers. NBER Working papers No. 8130, National Bureau of Economic Research, 2001.

7. Diekmann F, Batte M. Examining information search strategies of Ohio farmers. Journal of Extension, 2009, 47(6).

8. Demiryürek K. The analysis of information systems for organic and conventional hazelnut producers in three villages of the Black Sea Region, Turkey, PhD Thesis, The University of Reading, Readings, 2000.

9. Demiryürek K, Erdem H, Ceyhan V, Atasever S, Uysal O. "Agricultural Information System and Communication Networks: The Case of Dairy Cattle Farmers in Samsun Province of Turkey". Information Research. 2008; 13:343.

10. Demiryürek K. "Analysis of information systems and communication networks for organic and conventional hazelnut producers in the Samsun province of Turkey". Journal of Agricultural Systems, 2010.

11. Dereje Derso, Ekuogbe Ejiro. African Journal of Agricultural Science and Technology (AJAST). http://www.oceanicjournals.org/ajast ISSN 2311-5882 (C)2015 Oceanic Journals the contribution of information and communication technologies to the Ethiopian agricultural extension system: a review of literature on agriculture knowledge management. 2015; 3(9):407-411.

12. Gulati Archana. "Dialing in rural prosperity through universal cellular connectivity"-Kurukshetra-A Journal of Rural Development, Ministry of Rural Development, Government of India, 2008, 57(1). ISSN-0021-5660.

13. Gakuru K, Winters F. Stepman "An inventory of Innovative Farmer Advisory Services" Forum for Agricultural Research in Africa, December 29 2008.

14. Gigler BS. Including the excluded-Can ICTs empower poor communities? Towards an alternative evaluation framework based on the capability approach. Paper presented at the 4th International Conference on the Capability Approach, Pavia, 2004.

15. Hargittai E, Hinnant A. Digital inequality: Differences in young adults' use of the Internet. Communication Research. 2008; 35(5):602-621.

16. Mengistu Meresa. The role of agricultural extension service on agricultural development: The case of Walayta Sodo Zuria District, Ethiopia. Int. J Agric. Extension Social Dev. 2020;3(1):07-13.

17. Indiresan PV. Technology planning for rural development. IASSI quarterly. 1989; 8 (1):52-63.

18. ITU. Information Society Statistical Profiles 2009 Africa, ITU Telecommunications Development Bureau Geneva Switzerland, International Telecommunication Union, 2009.

19. Jangid, Umesh Arya. Information technology: boon or bane. Ed by Kiran Prasad. Information and communication technologies; recasting development, New Delhi: BR, 2004, 67-80.

20. Jafri A, Dongre A, Tripathi V, Aggrawal A, Shrivastava S. 'Information Communication Technologies and Governance: The Gyandoot Experiment in Dhar District of Madhya Pradesh, India.' ODI Working Paper 160. London: ODI, 2002.

21. Jones GE, Rolls MJ, Tranter RB. Information Management in Agriculture. British Library R\&D Report 
5931. AERDC, the University of Reading, Reading, 1987.

22. Julie Jacobson and Regina Rabinovich. A10the Bill \& Melinda Gates Foundation Approach and Strategy to the Neglected Tropical Diseases, 1998-2010.

23. Koutsouris A. Innovating towards sustainable agriculture: A Greek case study. The Journal of Agricultural Education \& Extension. 2008; 14(3):203-215.

24. Kirub L. Information and Communication Technologies in Ethiopia: Past, Present and Future Potential for Social and Economic Development. Professional Association Workshop, Addis Ababa, Ethiopia, 2008.

25. Kizilaslan N. "Agricultural information systems: a national case study". Library Review. 2006; 55(8):497507.

26. Lishan A. Information and Communication Technologies in Ethiopia: Past, Present and Future Potential for Social and Economic Development. Professional Association Workshop, Addis Ababa, Ethiopia, 1999.

27. Michiels SI, Van Crowder L. 'Discovering the 'Magic Box': Local Appropriation of Information and Communication Technologies (ICTs).' SDRE, FAO, Rome, 2001.

28. Malik, Netrapal, Bharadwaj, Neelam. Village information centers: a strategy of using information technology for rural development”. IASSI quarterly. 2001; 19(3):103113.

29. Maningas RV, Perez VO, Macaraig AJ, Alesna WT, Villagonzalo J. "Electronic Information Dissemination through the Farmers' Information and Technology Services (FITS)/Techno Pinoy Program. Bringing Information and Technology within the Reach of the Farmers. 2005". from http://jsai.or.jp/afita/afitaconf/2000/part08/p231.pdf, 2000

30. Mittal S, Mehar M. An assessment of farmer's information networks in India-role of modern ICT, 2015. CGIAR.org;2015.Link:http://www.afita.org/graph/web_s tructure/files/Seminar\%20 (07)-02(1).pdf.

31. Mulat D, Tadesse B. ICT Penetration and Usage in Ethiopia: Baseline Study: Department of Economics, Faculty of Business and Economics Addis Ababa University, Ethiopia, 2002.

32. MOA Information Centre. Summary of contemporary Chinese approaches of ICT-based agricultural information dissemination. Research Report published by Information Centre, Minister of Agriculture (MOA), P.R. China, 2014.

33. Nisansala P. Vidanapathirana Agricultural information systems and their applications for development of agriculture and rural community, a review study University of Turku, Turku School of Economics, Finland.

34. Neelameghan A. Information technology and rural development. Information studies. 1998; 4(1):55-61.

35. Oladele OI. Extension communication methods for reaching small-ruminant Farmers in South Western Nigeria. 26th Annual Nigerian Society of Animal production Conference, Kwara Hotels, Ilorin, 1999.

36. Opara UN. "Agricultural Information Sources Used by Farmers in Imo State, Nigeria". Information Development. 2008; 24(4):289-295.

37. Ortiz O. The information system for IPM in subsistence potato production in Peru: experience of introducing innovative information in Cajamarca Province, The University of Reading, Reading. Ozowa, 1997.
38. Syama Thrimurthy P. "Information communication technology for rural areas"-Edited by $\mathrm{P}$ Adinarayan Reddy-Science and Technology for Rural developmentThe Associated Publishers, New Delhi, 2009.

39. Ramkumar SN. The analysis of farmer information systems for feeding of dairy cattle in two villages of Kerala State, India, The University of Reading, Reading, 1995.

40. Rees D, Momanyi M, Wekundah J, Ndungu F. Agricultural knowledge and information systems in Kenya-implications for technology dissemination and development. Agricultural Research \& Extension Network, Network Paper 107, 2000.

41. Rivera W. 'Agricultural and Rural Extension: Options for Reform.' In collaboration with Extension, Education and communication Service, SDRE, FAO, Rome, 2001.

42. Röling NG. Extension Science. Information System in Agricultural Development, Cambridge University Press, Cambridge, 1988.

43. Rolls MJ, Hassan SHJ, Garforth CJ, Kamsah MF. The agricultural information system for smallholder farmers in Peninsular Malaysia. Rural Extension and Education Research Report No. AERDD, the University of Reading, Reading, 1994.

44. Rolls MJ, Slavik M, Miller I. Information systems in Czech agriculture: sources and transfers of information for small and large scale farmers, new cooperatives and company farms. Rural Extension and Education Research Report No.11. AERDD, the University Reading, Reading, 1999.

45. Rolls MJ, Slavik M. Change in information systems in Czech agriculture: change during 1998-2003 in sources, transfer and the management of information for small and large scale private farmers, new cooperatives and company farms. Czech University of Agriculture, Prague, 2003.

46. Reddy, Naresh. IT for governance: opportunities. Information technology for participatory development. New Delhi: Centre for information research and development, 2003, 135-142.

47. Swanson BE, Rajalahti R. Strengthening Agricultural Extension and Advisory Systems: Procedures for Assessing, Transforming, and Evaluating Extension Systems. Agriculture and Rural Development Discussion Paper 45. Washington, D.C: World Bank, 2010.

48. Start D. The Rise and Fall of the Rural Non-Farm Economy: Poverty Impacts and Policy Options.' Development Policy Review. 2002; 19(4):491-506.

49. Starasts AM. Battling the Knowledge factor: A Study of Farmers' Information Seeking Learning and Knowledge Process with an online environment in Queensland. Unpublished Ph.D Thesis, 2004.

50. Van Den Ban, Hawkins HS. Agricultural Extension. Second edition. Blackwell Sciences Ltd. Carlton, Victoria, Australia, 1996.

51. Yun Zhang A, Lei Wang A, Yanqing Duan B. Information Processing In Agriculture journal homepage: www.elsevier.com/locate/inpa Agricultural information dissemination using ICTs: A review and analysis of information dissemination models in China, 2016;3:1729.

52. Haviarova E, Vlosky R. A Recipe for Creating a Web-Based Virtual Community. Journal of Extension, 2009, 47(4). 